\title{
Thinking Nation and Hybrid Belongings: The Aesthetics of Negotiation in Recent Media Art
}

\section{Christine Ross}

Volume 24, numéro 1, 1997

URI : https://id.erudit.org/iderudit/1071704ar

DOI : https://doi.org/10.7202/1071704ar

Aller au sommaire du numéro

\section{Éditeur(s)}

UAAC-AAUC (University Art Association of Canada | Association d'art des universités du Canada)

\section{ISSN}

0315-9906 (imprimé)

1918-4778 (numérique)

Découvrir la revue

Citer cet article

Ross, C. (1997). Thinking Nation and Hybrid Belongings: The Aesthetics of Negotiation in Recent Media Art. RACAR : Revue d'art canadienne / Canadian Art Review, 24(1), 42-51. https://doi.org/10.7202/1071704ar

\section{Résumé de l'article}

Dans La Communauté des Citoyens, la sociologue Dominique Schnapper définit la nation comme une communauté abstraite de citoyens dont l'unité est garantie par un corps politique qui arrache l'individu de ses appartenances religieuses, dynastiques et ethniques pour " unifier les hommes ». En tant que principal processus de collectivisation de l'ère moderne, la nation performe la transcendance du local en supprimant graduellement les différences à l'intérieur pour accentuer les différences par rapport à l'extérieur, favorisant ainsi un processus d'homogénéisation. Les principales questions qui sous-tendent le présent article sont les suivantes : l'art actuel est-il critique de la nation? Dans l'affirmative, quelles sont les stratégies esthétiques mises en oeuvre dans l'élaboration d'une telle critique? En quoi le processus national d'homogénéisation fait-il place à d'autres modes d'appartenances? L'essai se penche sur trois oeuvres vidéo canadiennes réalisées pendant les années 1990, Yes Sir, Madame... de Robert Morin, Conditional Love d'Ardele Lister et Vexation Island de Rodney Graham, dans le but d'examiner leur représentation de l'appartenance « canadienne » à travers le questionnement de la nation. Ces trois oeuvres médiatiques articulent une esthétique de négociation qui met en place un mode d'appartenance nationale intermédiaire qui remet en cause la conception d'un " Canada unifié ».
Tous droits réservés @ UAAC-AAUC (University Art Association of Canada | Association d'art des universités du Canada), 1999
Ce document est protégé par la loi sur le droit d'auteur. L’utilisation des services d'Érudit (y compris la reproduction) est assujettie à sa politique d'utilisation que vous pouvez consulter en ligne.

https://apropos.erudit.org/fr/usagers/politique-dutilisation/ 


\title{
Thinking Nation and Hybrid Belongings: The Aesthetics of Negotiation in Recent Media Art
}

\author{
Christine Ross, McGill University
}

$\mathrm{D}$ ans Lo Communauté des Citoyens, la sociologue Dominique Schnapper définit la nation comme une communauté abstraite de citoyens dont l'unité est garantie par un corps politique qui arrache l'individu de ses appartenances religieuses, dynastiques et ethniques pour «unifier les hommes ». En tant que principal processus de collectivisation de l'ère moderne, la nation performe la transcendance du local en supprimant graduellement les différences à l'intérieur pour accentuer les différences par rapport à l'extérieur, favorisant ainsi un processus d'homogénéisation. Les principales questions qui sous-tendent le présent article sont les suivantes : I'art actuel est-il critique de la nation? Dans l'affirmative, quelles sont les stratégies esthétiques mises en œuvre dans l'élaboration d'une telle critique? En quoi le processus national d'homogénéisation fait-il place à d'autres modes d'appartenances? L'essai se penche sur trois œuvres vidéo canadiennes réalisées pendant les années 1990, Yes Sir, Madame... de Robert Morin, Conditional Love d'Ardele Lister et Vexation Island de Rodney Graham, dans le but d'examiner leur représentation de l'appartenance « canadienne » à travers le questionnement de la nation. Ces trois œuvres médiatiques articulent une esthétique de négociation qui met en place un mode d'appartenance nationale intermédiaire qui remet en cause la conception d'un «Canada unifié ».

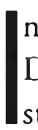
La Communauté des citoyens, the French sociologist Dominique Schnapper defines the modern nation as an abstract "community of citizens" whose unity is guaranteed by a political body which has replaced religious, dynastic and ethnic communities to "unify people". ${ }^{1}$ The nation unifies beings, but it does so only by pulling out, by tearing off the individual from the limitations inherent to his or her belonging to a particular group. ${ }^{2}$ This means that the modern nation activates a split with ethnic belongings and with any forms of belonging lived as natural by the individual. This split may seem violent, yet for Schnapper, it is the main condition of possibility of nationhood. But like many thinkers writing today on the question of nation, Schnapper observes a crisis. The reinforcement of productivist socieries, the development of globalization and the rise of nationalistic claims by ethnic groups seeking recognition as nations have weakened the political principle, which in turn has weakened the social bond. ${ }^{3}$ Even though she champions nation, she sees cause for alarm: "Nothing guarantees that the modern democratic nation will still have in the future the capacity to ensure the social bond as it did in the past". ${ }^{4}$

Nation is not an easy term to define. A modern phenomenon whose initial elaboration may be traced back to premodern societies but whose foundations are historically situated in the seventeenth and eighteenth centuries, a holdall concept referring to polymorphous realities, a notion that has become as vague as the notions it refers to (such as culture, universalism and the will to live together), it has nevertheless been the main means of collecrivization in the modern era. ${ }^{5}$ Such diverse thinkers as Homi Bhabha, Yael Tamir, Gérard Bouchard and, to a certain degree, Schnapper have argued that, notwithstanding this conceptual vagueness, the modern constitutions of nation have this in common: that they establish themselves by transcending local powers, and by attempting to suppress the eth- nic, cultural, linguistic, religious and gender differences between communities. ${ }^{6}$ As Yael Tamir maintains, this process of homogenization takes place by gradually erasing the differences from within so as to accentuate the differences from without, a process which strengthens the citizen's awareness of borders and separates "us" from "them". I In other words, each citizen is compelled to forget his or her particular belongings to be part of a nationally bordered social order. But as contemporary nationalist, feminist, neo-immigrant and ethnic group claims have made manifest, complete oblivion of particularisms did not occur and communities have struggled, are struggling more and more, for the recognition of their differences. We are now witnessing the breakdown of a national paradigm based on homogenization and possibly the beginnings of another paradigm, which would allow for the redefinition of unity through difference. This essay is an attempt to examine how recent media art represents this transitional moment and how image technologies are explored in contemporary art's questioning of nationhood, so that one may start to understand if and how new national paradigms are slowly emerging in the western world.

Schnapper's definition of the modern nation is extremely useful for the present problematization of nation as the "only" means of legitimate social bonding. It emphasizes the abstract nature of nation, that is, the pulling out or arrachement from particular forms of belonging that has to take place in order to achieve national universalism. Following Bruno Latour's definition of modernity as a project of purification of categories, as an ongoing attempt to separate the human and the nonhuman (i.e. the subject and the object, culture and nature), ${ }^{8}$ modern nation may be described as a project which seeks to separate the citizen from his or her "natural" belongings. But, and this is where Schnapper's uncritical reinforcement of nation as arrachement needs to be problematized, modern nation is also about inter- 
mediacy and hybridity. As Latour maintains, modernity is also paradoxically about the creation of quasi-objects or quasi-subjects who incessantly proliferate because of modernity's faithfulness to purifying practices which prevent it from considering the mixture of categories:

\begin{abstract}
Moderns do differ from premoderns by this single trait: they refuse to conceptualise quasi-objects as such. In their eyes, hybrids present the horror that must be avoided at all costs by a ceaseless, even maniacal purification. [...] There are as many purification processes as there are collectives. But the machine for creating differences is triggered by the refusal to conceptualise quasi-objects, because this very refusal leads to the uncontrollable proliferation of a certain type of being: [...] [ $t$ ]hese nonhumans possess miraculous properties because they are at one and the same time both social and asocial, producers of natures and constructors of subjects. They are the tricksters of comparative anthropology. [...] Worlds appear commensurable or incommensurable only to those who cling to measured measures. Yet [...] nothing is, by itself, either reducible or irreducible to anything else. Never by itself, but always through the mediation of another.
\end{abstract}

Hence, as nation attempts to purify the individual of his or her ethnicity, it also creates hybrids because of its "refusal to conceptualize" them. Hybrids are quasi-objects or quasi-subjects who do not completely comply with the "measured" abstraction of the national and who bring into play complex networks of negotiations, mediations and intermediate organizations between the particular and the universal, between nature and culture. So the question emerges: what constitutes belonging when it puts into crisis the holistic view of the nation? Furthermore: how does one represent hybrid belongings? How are image technologies explored so as to problematize what Bhabha has termed the "pedagogical" 10 nation (the normative homogenized view of nationhood)?

This essay is about how recent media art rethinks belonging in the midst of the questioning of the national. It addresses three Canadian art works from the 1990s that, together, arriculate a renewed sense of "Canadian" attachment. These works elaborate what I would call an aesthetics of negotiation, which is for me the locus of hybridity. If this concept is to be useful at all, however, we need to keep in mind the contingent and contradictory nature of the negotiations it underlies. My intention here is to complexify hybridity by emphazising the networking of its mixtures instead of merely stabilizing its achievement. This objective is motivated by my belief in the potential flexibility of "New World" nations. As the historian Gérard Bouchard has argued, the new Western communities which emerged in and soon after the sixteenth century, in
Canada, Latin America, the United States and Australia, were exposed from the start to indigenous and immigrant groups with whom they had to negotiate in order to constitute themselves as nations. Bouchard maintains that these new nations were not models of tolerance - they have continually attempted to suppress differences through such violent practices as genocide, deportation, forced interbreeding and sterilization of nonwhite individuals - but because of the resistance of different cultural collectivities, they have become more productive in inventing ways to reconcile differences, in opposition to France, for example, where cultural and religious differences have yet to be officially recognized. ${ }^{11}$ In this context, it is imperative to examine the type of negotiations at play in media representations of nationness and to see how they problematize unity by diversity. In their use of image technologies, the three art works share the following feature: they surge the abstraction of a unified "Canada" so as to put into play an intermediate space of negotiation between linguistic, ethnic and technological categories. In this liminal space, national belonging is defined as an inbetween process of attachment. This is why I have called the three works the "negotiation works".

\section{Negotiation work no. I}

In 1994, in a period of intense constitutional debates on Canadian unity, after the failure of the two attempts to bring Quebec into the Canadian constitution (the 1987 Meech Lake Accord and the 1992 Charlottetown Accord) and just before the fall of 1994 when the prospect of a vote on sovereignty re-emerged in Quebec leading to the 1995 Quebec Referendum, Robert Morin released a 75-minute video film - a film exclusively distributed on video - entitled Yes Sir! Madame... A project twenty years in the making, the work was constructed from footage filmed by Morin since his teenage years. It stages the life story of Earl Tremblay, a bilingual Canadian, son of a francophone father and an anglophone mother, who attempts to find his place in the social order by moving from the Maritimes' countryside to Quebec's urban metropolis, by living as an itinérant and a squatter, changing homes and switching jobs until he suddenly disappears while working as a federal deputy in the Mulroney Conservative government. Anticipating his own disappearance, Tremblay left behind him nineteen rolls of film shot with the Bolex camera he inherited from his mother after her death.

These assembled nineteen rolls, each three minutes long, form the narrative of Yes Sir! Madame ... The images are narrated by Morin himself who speaks the entire voice-over and performs the non-verbal sounds of the action. The key feature of this narration is its bilingualism. This means that each utterance is spoken by Morin in French and in English, the two official languages of Canada, making this film as Tremblay/ 
Figure I. Robert Morin, Yes Sir! Madame ..., video, 1994 (Photo: courtesy of Coop Vidéo de Montréal).

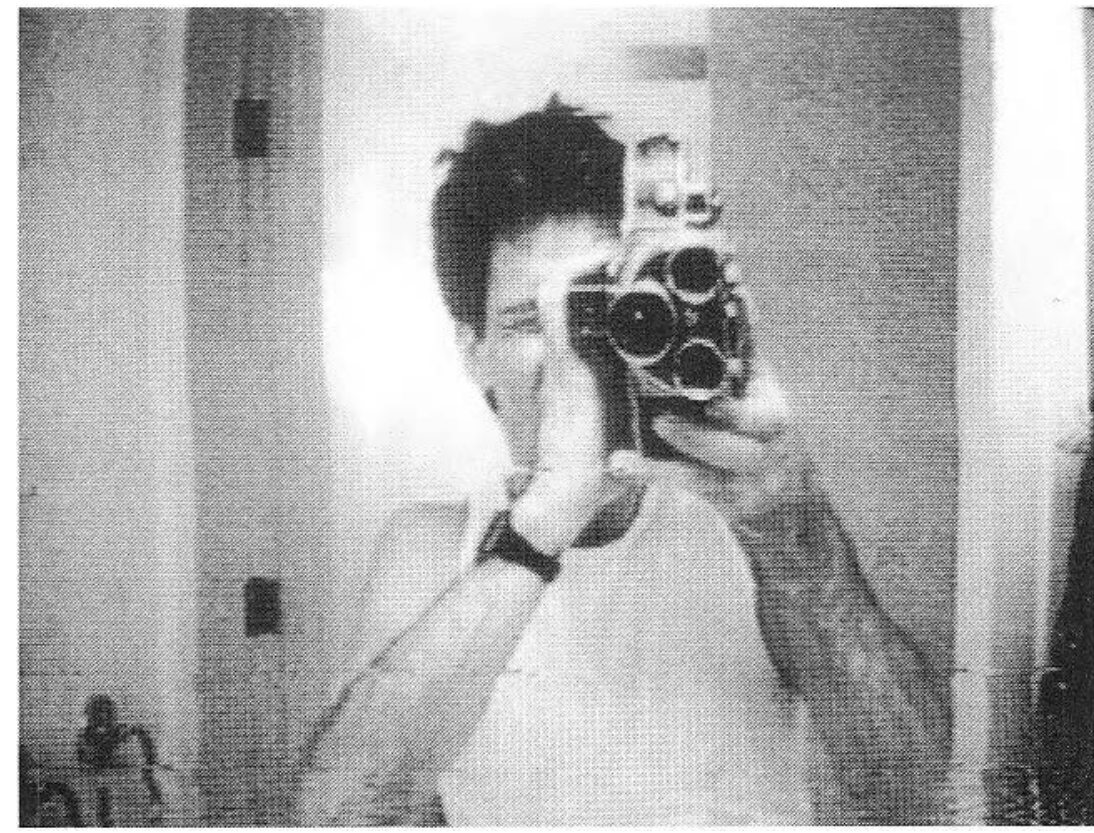

Figure 2. Robert Morin, Yes Sir! Madame ..., video, 1994 (Photo: courtesy of Coop Vidéo de Montréal).

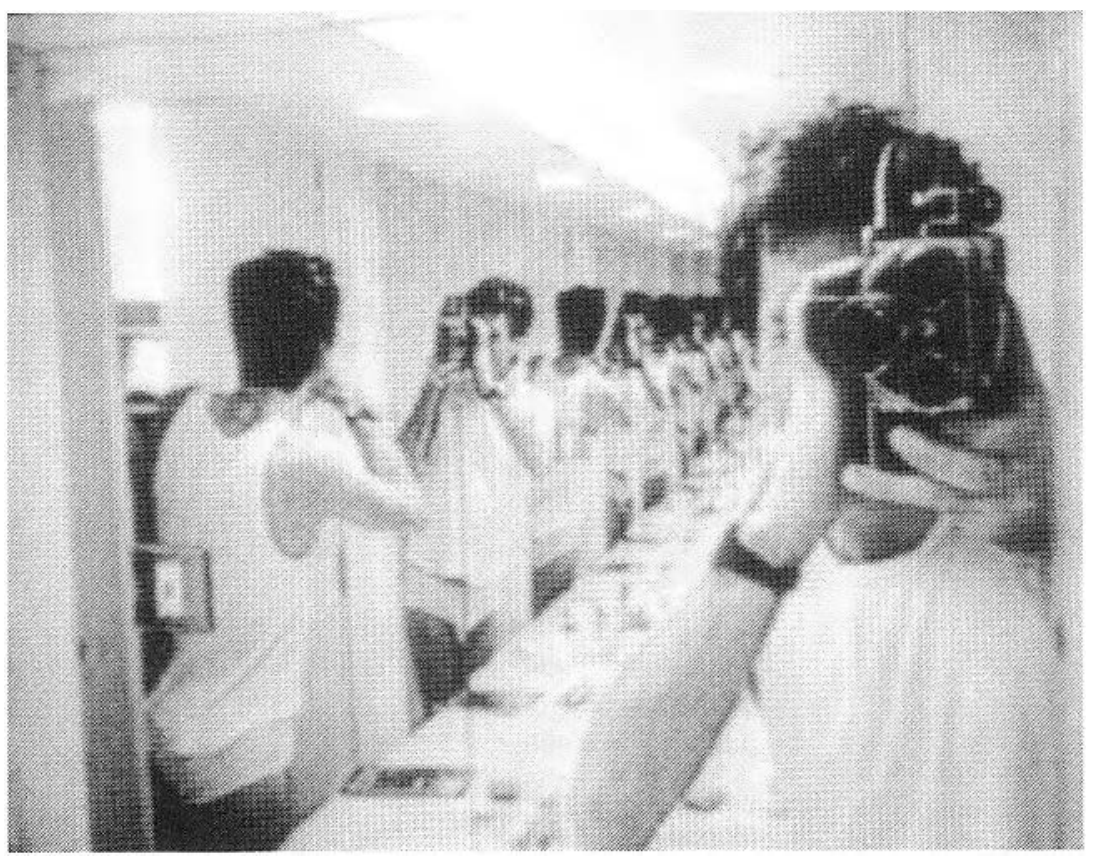

head", who has merged with a low-resolution technology to observe his reality and inscribe himself in his immediate environment, looks at himself in a two-valved mirror and activates a gap between the left and the right mirror in which his reflection is not only split but multiplicd by camera feedback (fig. 1 and 2): "[...] I faced us, and there was a lot of them. On s'est fait peur pour vrai. We were all there. On était tous là. All the peasoups on the one side. Toutes les têtes carrées de l'autre bord. The fight would have been a massacre. La bataille aurait pu être mortelle pour tout le monde. The only reasonable solution was to split. Fait qu'on a décidé de se séparer. For good. Pour de bon. Yes Sir! Oui Madame! Bonne chance. Good Luck." This split constitutes itself through what Camilla Griggers has designated as a surge - a "sudden acceleration of sign-flow away from established meanings," 12 schizophrenia being the forceful movement which puts the unity of the self into crisis and makes manifest the abstract social identity of the "Canadian."

What is crucial to emphasize here is that the surge in Yes Sir! Madame ..., its schizophrenic drive, is not shown as occurring within the individual psyche of Morin/Tremblay but within the social linguistic space of the nation. It brings into crisis the Canadian nation whose ideal unity, since the decree of the Law of Official Bilingualism by the Trudeau government in the early 1970s, has been constructed by panCanadian bilingualism. Passed by Trudeau to counter Quebec nationalism and to overcome Quebec's historical perception of itself as a "distince socicty," the law was to unite Canadians. In 1988, Trudeau thus affirmed: "Bilingualism unites people; dualism divides them. Bilingualism means that you can speak to each other; duality means you can live in one language and the rest of Canada will live in another language."13 As the political scientist Kenneth

Morin observes "a real fucking Canadian movie $\mid$...] un christ de bon film canadien". But, and this is the drama of Yes Sir! Madame ..., as the identity quest progresses, the translation from one language to the other starts to operate a split, creating a progressive gap between the francophone and the anglophone Tremblay. Slippage starts to occur. Misinterpretations, reinterpretations, denials, schizophrenia. In the fourteenth roll, Earl, the guy with the camera "practically glued to [his] foreMcRoberts has recently demonstrated, the Law of Official Bilingualism was from the outset detached from any form of biculturalism. Its purpose was to support the development of the French language throughout the country without supporting its culture, which was to become a culture like the others through a policy of mulciculturalism. ${ }^{14}$ Established in a period of decline of the British empire, official bilingualism and the policy of multiculturalism were strongly supported by English 
Canada which was searching for its own nationalist identity and traditionally perceived Canada not as a double compact of "two founding peoples" but as a compact between provinces. In short, since the 1970s, the nation has been, and I am adopting here Benedict Anderson's definition of nation as an imagined political community, ${ }^{15}$ re-imagined into existence as a unity to be achieved by splitting francophone language and culture and by indirectly reinforcing two different visions of Canada. As Bouchard puts it, Canada "has failed the test of difference" because of its inability to recognize the distinctiveness of French Quebecois culture; it was able, however, to conceive of a politics of multiculturalism to support, to a certain degree and by attempting to reduce ethnic cultures to folklore, ${ }^{16}$ the diversity of non-English Canadian communities. ${ }^{17}$

In Yes Sir! Madame ..., the Canadian is a bilingual being, yet s/he does not correspond to what Jan Nederveen Pieterse designates as a mere "mixing of cultures" 18 which has come to define hybridity. The French Canadian's bilingualism is not a mixture but a disconnection from self, his or her past, culture and community, it is a split between what seems more and more like two irreconcilable visions of Canada. To belong here is not to mix or to unite; it is rather to live in the growing gap between the francophone and the anglophone while attempting to narrate and to interpret in the present (by voice-over) the images from one's past. Earl Tremblay's voice-over performs a bilingual linguistic gap to provide meaning to the visual inconsistencies of the image, but in doing so he posthumously puts into play a space of growing incompatibility between two cultures in order to make sense of his own split identiry, acting out a language which has been compelled to forget its culture for the sake of the homogenizing process of modern nation. This hybrid gap re-stages bilingual Canada so as to, in Bhabha's terms, "refigure it as a contingent 'in-between' space." 19

In the early 1970s, video art was theorized by Rosalind Krauss, amongst others, as an aesthetics of narcissism. The indexical nature of the image, i.e. the technical capacity of video to shoot and transmit an image at the same time, was seen as creating for the artist and for the viewer confusion between self and image, absorption of the image by the self. Yes Sir! Madame ... problematizes this technological determinism by activating an extreme dis-confusion by which the I cannot recognize himself in the image in a unified way. Unity of self and other, even fantasmatic unity, is broken. If Earl, this strange surveillance cyborg, is to reconstruct himself, it is within the split that video/film activates between two mirrors, two visions, two languages. Belonging lies in the technological splitting of narration which splits the cohesive view of bilingual Canada so as to create a gap, which may allow the viewer, perhaps Earl himself, to grieve wholeness and to conceive connection through disconnection. The thrust is to inhabit the gap while gapping the habitat. This process activates the breakdown of the national paradigm of homogenization and opens up new ways of imagining nation. It also reinforces Yael Tamir's hypothesis that a new paradigm is indeed taking place in recent conceptualizations of nation, one that articulates a gap between two categories which have been overlapping for centuries but which need to be slightly separated, the gap between nation and state. ${ }^{20}$

\section{Negotiation work no. 2}

The one-hour-long Conditional Love by Ardele Lister was released in 1998. Like Yes Sir! Madame ..., it may also be seen as a self-portrait, particularly if we keep in mind Raymond Bellour's theorization of the term as one of the key modes of narration in video art. The self-portrait brings into play not so much the story of one's life but the story of an ongoing quest for identity, a search narrated by the video artist who "starts with a question that reveals an absence to oneself." ${ }^{21}$ A Canadian artist who has been living in the United States for several years, Lister begins her self-portrait with the question "What is Canadian about me? " As the tape unfolds, we follow Lister's voice-over as she comments, questions and thinks about Canadian identity, presenting us with footage of post-WWII Hollywood films about Canada interlaced with family films and excerpts of interviews held with different Canadians asked to define their own perception of Canada.

I do not have space here to elaborate on the many facets of this videotape. What I want to emphasize is that video is being used by Lister to tell the story of an absence which is in fact the absence of Canadian cinematic representacions of Canada in the 1940s, 1950s and 1960s. As Hollywood cinema is being shown on the screen, she notes how the Canadian Co-operation Project had donated the feature film industry to the Americans. Until the mid-1960s, Canadian leaders failed to support the development of a Canadian feature film industry which would have been the means (this was, after all, the role of wartime and post-war national cinema) to provide Canadians with a recognition and mirroring device "necessary for developing a sense of self." In Conditional Love, video becomes the medium responsible for the representation and the storytelling of Canadian identity; it does what cinema has failed to do, but it does so, and this is crucial, only in as much as it "represents lack." Indeed, Lister's story is the story of Canada as lack. This non-identity is made manifest not only in the reproduction of different Hollywood films representing Canada from an American point of view, but also in the series of interviews where Canadians either fail to define Canadianness ("it is nothing" claims one participant), or succeed in defining it but only in relation to (fig. 3 and 4) and in an attempt to resist (fig. 5 and 6) American identity.

Indecisiveness is therefore created in that the video does 
Figure 3. Ardele Lister, Conditional Love, video, 1998 (Photo: courtesy of V tape, Toronto).

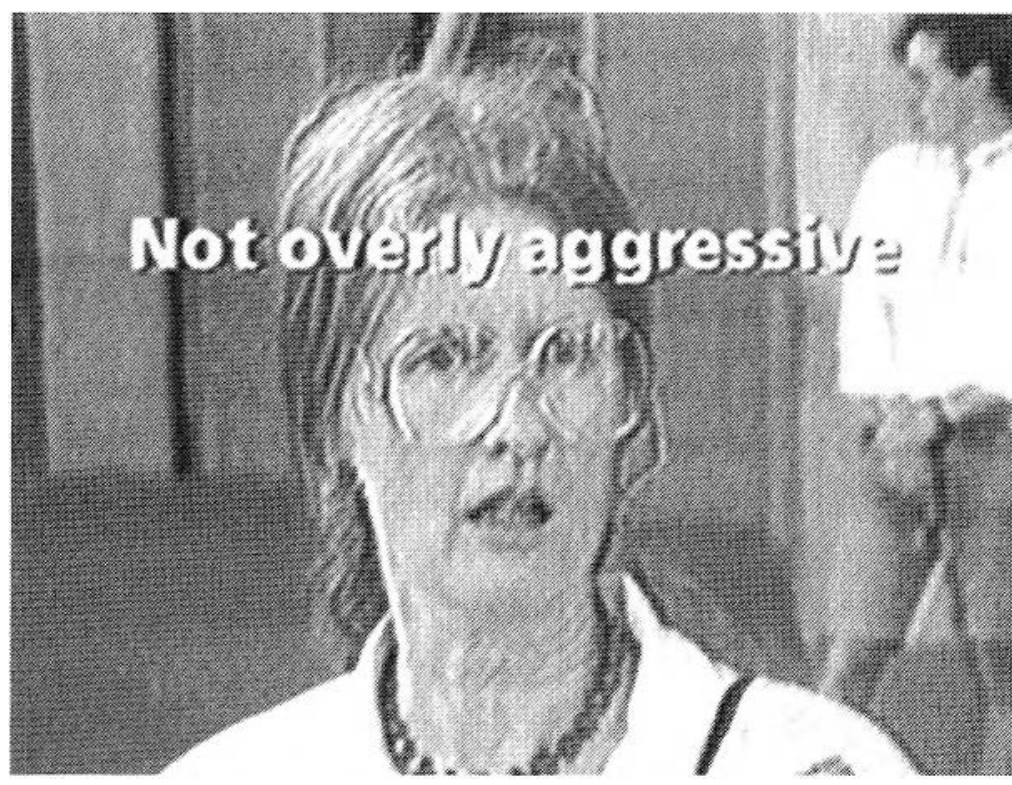

Figure 4. Ardele Lister, Conditional Love, video, 1998 (Photo: courtesy of V tape, Toronto).

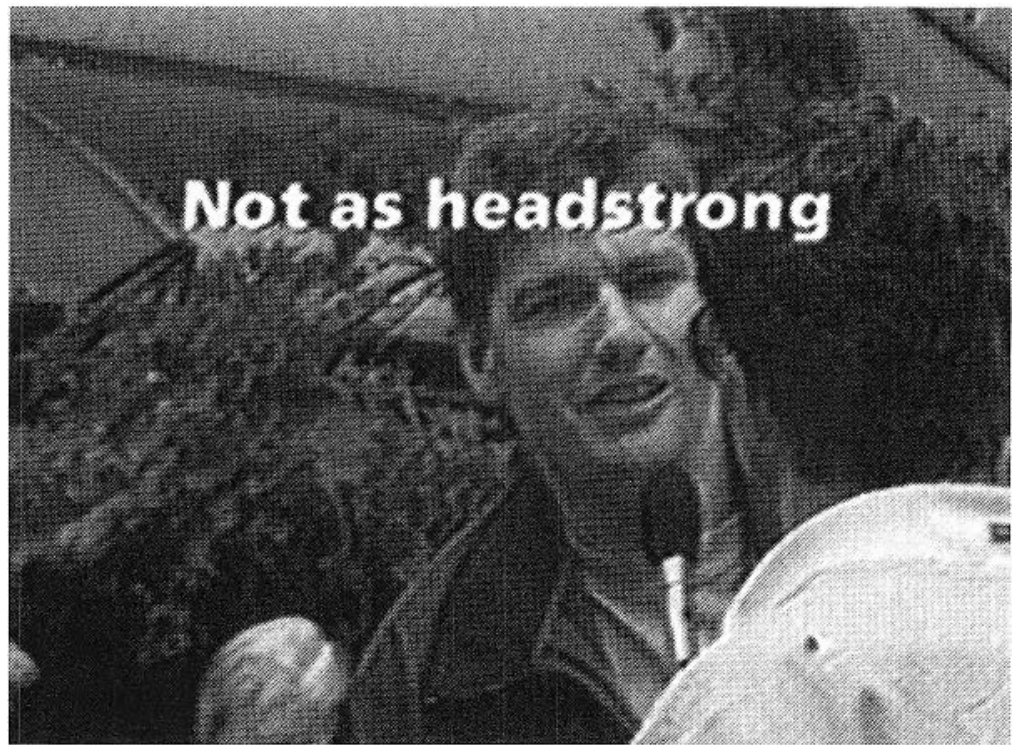

hold in the context of the recent Free-Trade Agreement which is perceived as yet another step in American absorption of Canadian identity. As the footage of American films and anti-Free-Trade demonstrations unfold, as Lister's voice-over fails to secure Canadian nationhood, a troubling question gradually emerges from Conditional Love: if one cannor represent nation, how can one even imagine the hybrid? In other words, is it possible to negotiate with no construct to negotiate with? These questions are not, cannot be, answered by a videotape which is about lack The function of video here is to reveal and question the failure of cinema in providing Canada with a representation of itself, articulating a revelation of absence, one that the voice-over insists upon even though Conditional Love is also composed of more recent films (from the 1960s and 1970s) on Canada produced by the National Film Board. Let us emphasize, however, that if the question of the representation of nation is not resolved, it is at least enunciated, and if this is so, it is because video is negotiating with cinema. A form of technological and narrative hybridity is at play between video and cinema, the present and the past. The productivity of this negotiation is that it represents Canada as a country where the vagueness of the concept of nation results from the incompleteness of its homogenization project that would have otherwise guaranteed its cohesion and sovereignty. The video narrative is ultimately about a nation that has never really succeeded in defining its existence because of its inability to establish a clear distinction between "us" and "them," between English Canadians and Americans. It shows how Canadians lack the sovereign political power to undo critically and creatively a paradigm of homogenization.

As video negotiates with cinema to provide a representation of Canada, its acknowledgement of lack opens up two possibilities with regard to Canada's future development of nationhood. The absence not fill the lack of cinema and does not resolve what it is to be a Canadian. Nor does it effectuate the breakdown of "Canada" as a cohesive norm as in Morin's Yes Sir! Madame ... On the contrary, for Lister, this cohesive construct has never really been imagined. Conditional Love narrates, from beginning to end, the absence of Canadian representation, a gap which has prevented the shaping of a unified whole, of an imagined community of citizens. The surge is not schizophrenic but depressed, melancholic, taking the form of a lament denouncing Canada as an empty signifier. For Lister, if Expo ' 67 seems to be a moment of imagined community, this imagination does not of a homogenizing discourse could mean a greater flexibility in reconciling unity and cultural diversity because a weaker identity is not trapped by the questions of mission and affirmation of superiority. But it could also mean an inaptitude for thinking, understanding and representing difference because difference can only be defined in connection with identity.

Negotiation work no. 3

Vexation Island is a film installation produced by Vancouver artist Rodney Graham for the 1997 Venice Biennial. This 35- 
Figure 5. Ardele Lister, Conditional Love, video, 1998 (Photo: courtesy of V tape, Toronto).

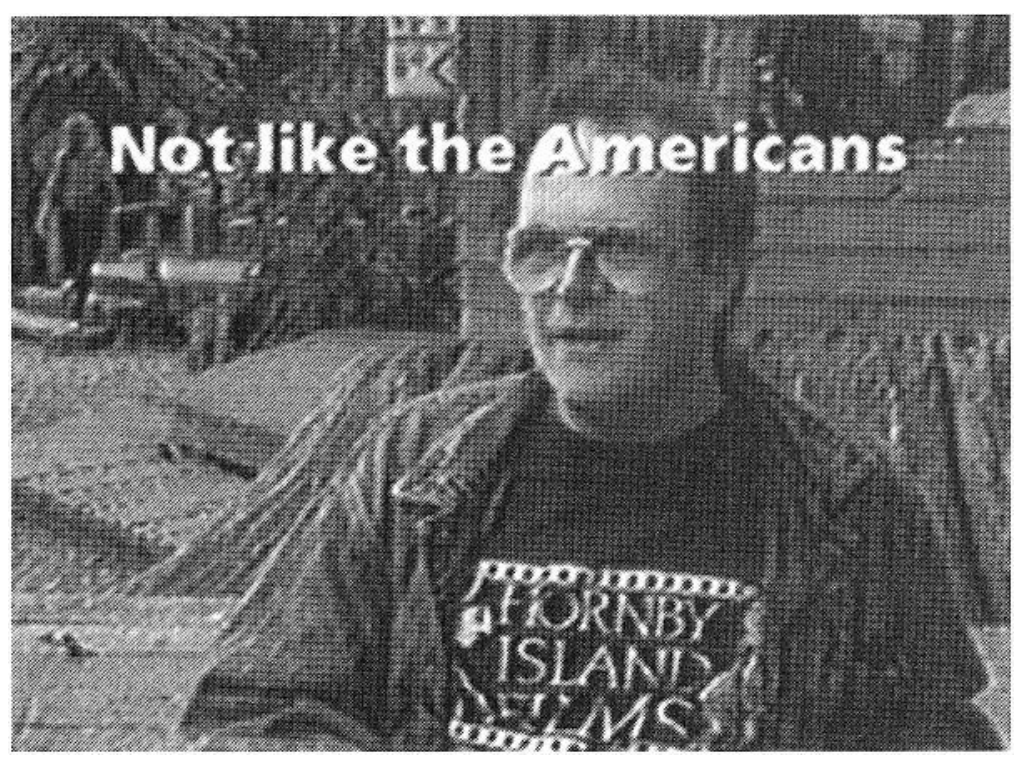

Figure 6. Ardele Lister, Conditional Love, video, 1998 (Photo: courtesy of V tape, Toronto).

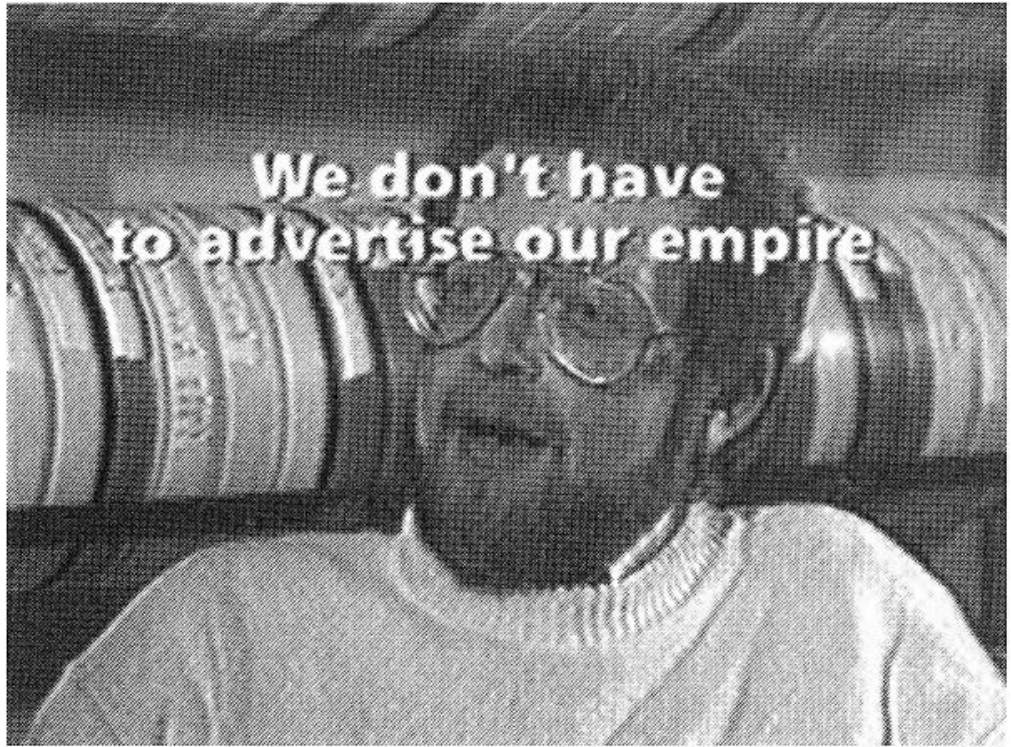

from the tree and hits him on the head. He falls unconscious again (fig. 9). This sequence will be continuously repeared for the duration of the viewing.

Where are we here? For sure, far away from Canada. But perhaps not so far away; these images may be exotic, but they are part of the Westerner's imagination, the Westerner's ability to imagine his or her nation into existence so long as s/he may also imagine an elsewhere to escape it. This imagination is facilitated by the adaptability of this elsewhere which in Vexation Island is, in fact, at the same time nowhere and beyond, a geographically un-located and uninhabited island whose points of references are the transcending infinite deep blue sea and light blue sky. Vexation Island's technology is significantly quite different from the low-resolution Yes Sir! Madame ... It provides us with a dream image which enchants the viewer by the high visual definition, rich colour contrasts, illuminating light, and crisp rendering of sound. Excess has replaced lack. For a while, as the floating disembodied eye of the camera approaches to give us an aerial view of the island, even the laws of gravity seem irrelevant.

While it stages an eighteenth-century Englishman, Vexation Island partakes of contemporary pleasure industries, such as tourism and television, in which aesthetics and anaesthesia, visual pleasure and projection meet to create evading images of the elsewhere. The imagined island is a phantasmagoria in the Benjamin sense of commodity-as-display, where, as Susan Buck-Morss explains, "exchange value no less than use value" lose practical meaning, and "purely representational value" comes to the fore. ${ }^{22}$ Vexation Island does not merely represent an island; it represents the representational value of the island, that is, the island as an image of evasion for the modern subject, the isolated ego seeking exoticism and wonder so as to escape its anxieties, burn-outs, disconnec-

mm colour film loop was presented in the Canadian pavilion, which was turned into a theatre by retaining the boards covering the pavilion's glassed courtyard that had been set up during the winter (fig. 7). This dark enclosed space (fig. 8) was composed of three main elements: a laser-disc video projector, a large 12-foot-long screen (placed against a wall and bolted to the end walls) and, in between the two, the public. The film features an eighteenth-century middle-class Englishman reminiscent of Robinson Crusoe, lying unconscious on the beach of a small tropical desert island. Near the body, a parrot speaks an incomprehensible language that finally awakens the castaway, who then gets up and starts to shake a palm tree. A coconut falls tion and other potential surges. As Robert Linsley observes, all modern dreams of insularity are dreams of a primitivist "lost home" which allows the Westerner to imagine a form of reconnection with nature and with the past, so as to make daily life bearable. ${ }^{23}$ This is what phantasmagoria is about: a visual, audio enchantment which numbs and suppresses disconnection between language, culture, work, memory and affect, a phantasmagoria reinforced by the large scale of the screen that expands the impact of the image.

But catastrophe haunts this technological imagination. Graham wants the viewer to experience lack amidst excessive beauty. Listen to the sounds of nature: as the camera lingers, 
Figure 7. Rodney Graham, Vexation Island, video, 1997 (Photo: Francesco Barasciutti).

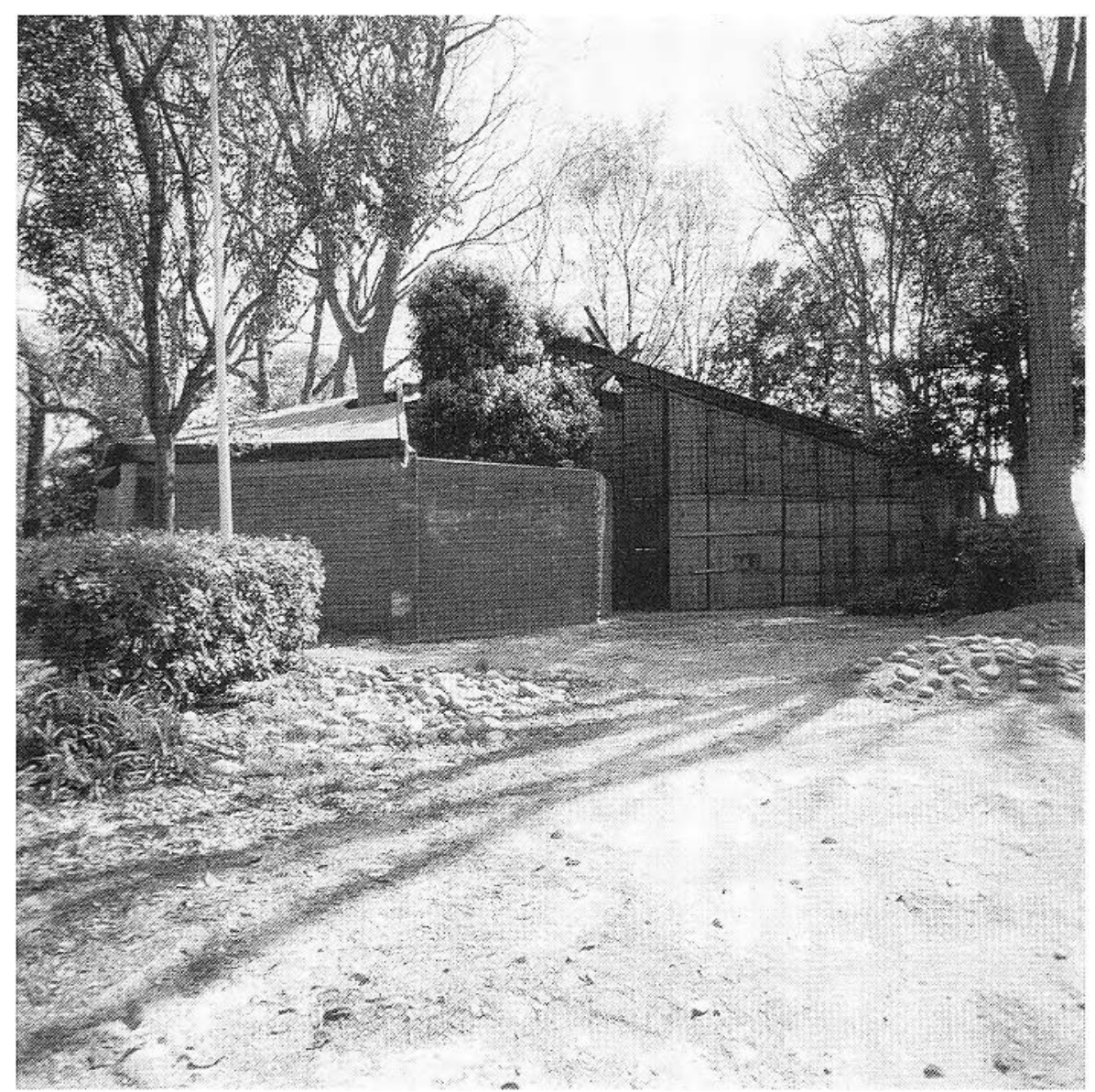

Figure 8. Rodney Graham, Vexation Island, video, 1997 (Photo: courtesy of Attilio Maranzano).

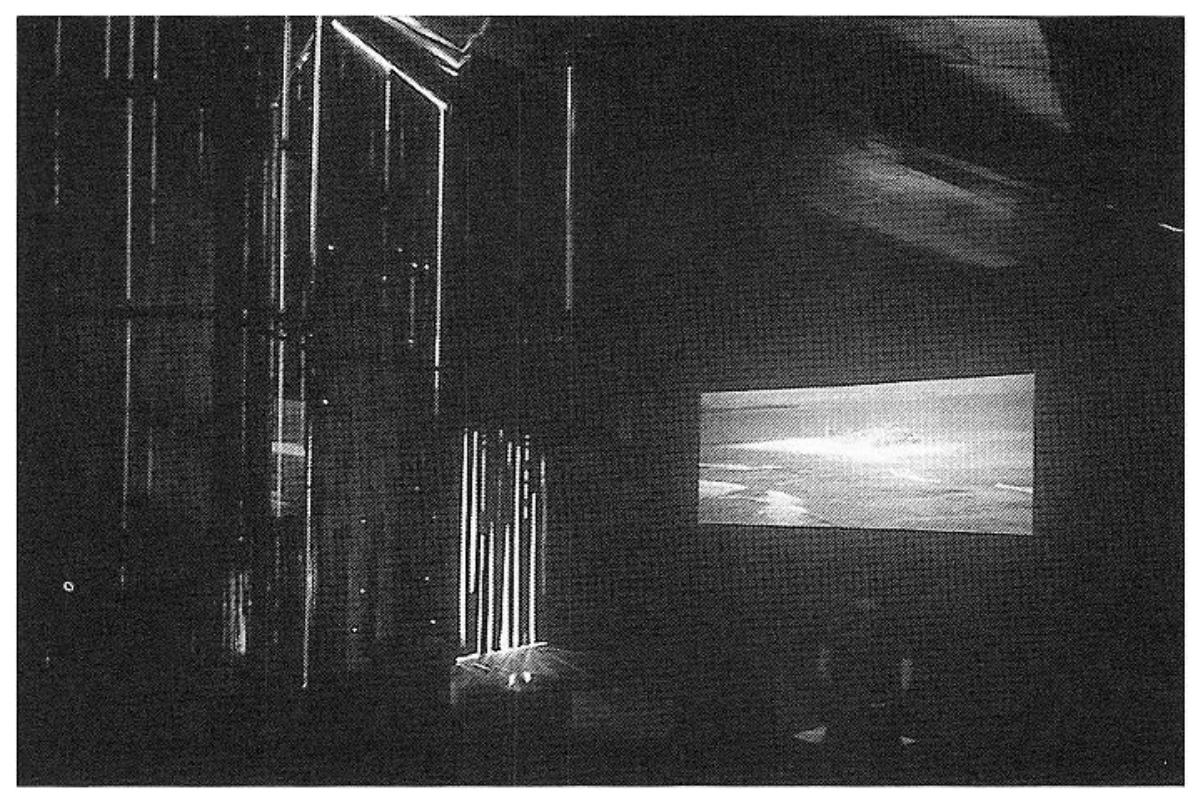

they become more and more overwhelming. The waves and the parrot are perhaps exotic, but this strangeness emphasized by the sound track bespeaks the uncontrollability of nature. Caught by the necessity of survival, the Englishman attempts to take control of his destiny, but nature responds like a fatality, negating the human effort, inscribing the subject in a Sisyphean process of eternal new beginning of the same. The surge here is on the side of nature; it is the forceful movement of the falling coconut and shot on the head that worries, lacks and vexes the dream image. Belonging is problematized by this surge as the viewer realizes that his or her dream does not provide a complete evasion from the here and now. Man - the castaway, the viewer - is still alone, himself an island, an island in an island in the midst of a gap between nature and culture, condemned to repetition, whose only companion is an incomprehensible parrot. Listen to the parrot: it enunciates this gap as it screams and cannot be understood. Bilingualism is not even an issue here, for the main issue is the Canadian's inability to be understood, to be listened to. The gap so characteristic of Yes Sir! Madame ... has resurfaced again, not as schizophrenia, however, but as a visual and aural experience between dream and redundancy, voice and deafness, culture and nature, man and society, English imperialism and exoric elsewhere, unity and difference, an in-between experience that holds excess and lack simultaneously to point out their necessary interdependence.

But Vexation Island is not just a film; it is first and foremost an installation, which pushes the questioning of the modern nation a bit further to propose what I would call an alternative. This alternative is not an alternative of content (a different definition of nation is not provided) but of image processing. To be more precise: the installation allows the viewer to become aware of his or her potential to change representations of na- 
Figure 9. Rodney Graham, Vexation Island, video, 1997 (Photo: courtesy of Shannon Oksanen).

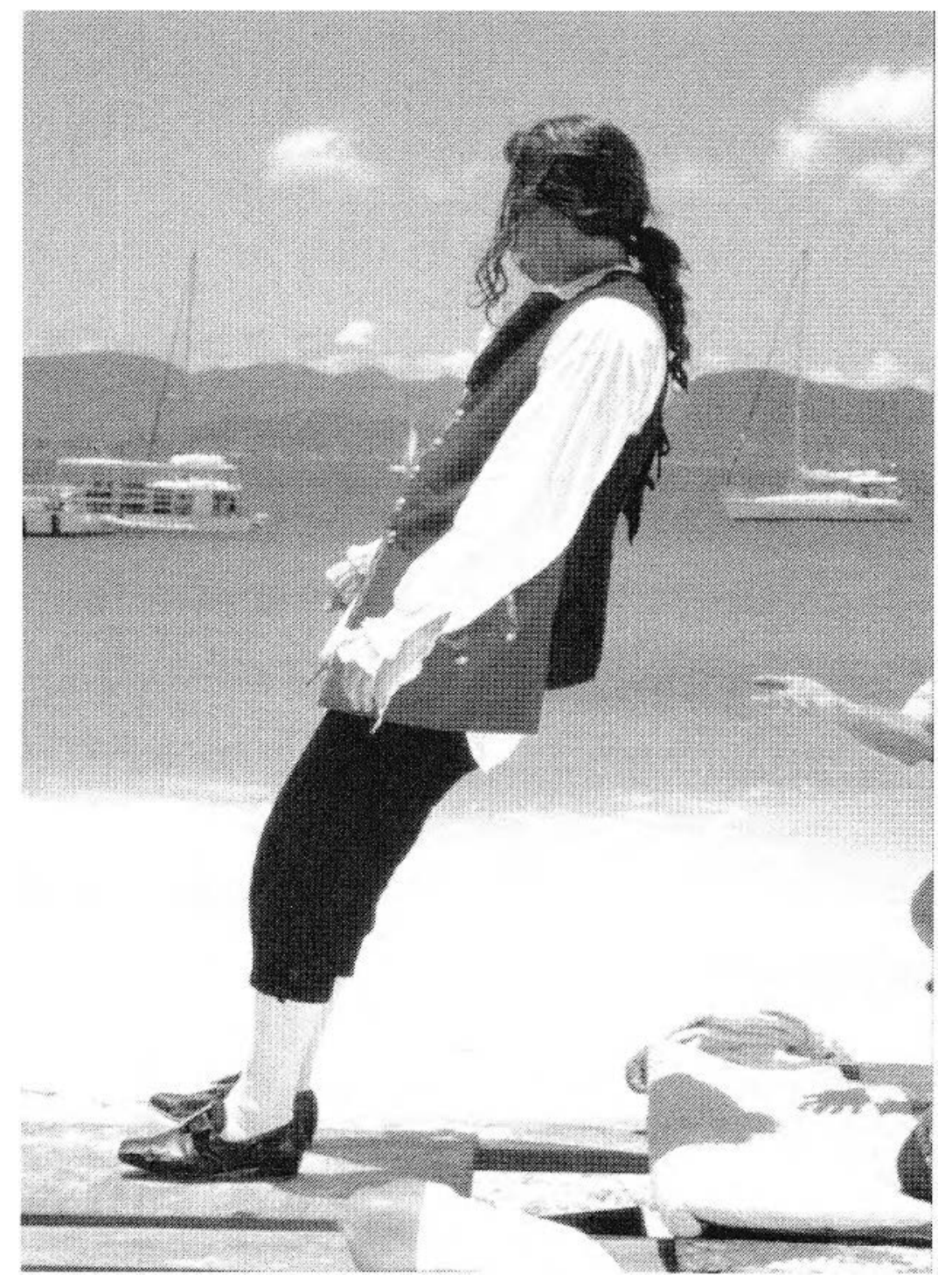

if not the in-between space of a camera obscura, what David Tomas has called the site of passage of the image, between the aperture from which the image emerges and the surface on which it is projected, that is, between the projection of the image by the video projector and its fixation on the screen. In this site, the question of belonging arises in the passage of the image, after its projection but just before its reification as phantasmagoria. In this interstitial space, Canadian belonging becomes a contingent transitional reality which is not "what we dream," "what we are" or "what is projected" but rather, as Deleuze and Guattari put it, a "becoming-other." 26 The site of the becoming-other of the image. The modern interstitial space of Vexation Island, between projection and fixation, is a gap that the viewer can physically occupy to negotiate the emergence of other representations of nation. No one in the room will see these new emergences because the installation is not technically interactive, but by situating the viewer in a dark enclosed space between projection and fixation, the installation structures a timespace where the projected image may be re-imagined before its manifestation on the screen. This is why the space can also be seen as a metaphor for the mind. In short, the underlying belief here is that representation is not always already reified, not always already determined. Resistance and change may occur berween the thinking, the viewing, the projection and the representation of nation.

When political scientists or philosophers such as Bhabha, Tamir, Bouchard and others postulate the end of the national paradigm of homogeniza-

tionhood. In fact, the only possibility of community lies not in the island image but in the dark enclosed room of the pavilion, the space interval where the projector, the screen and the bodies of the viewers are located. This space corresponds to the inside of a camera obscura, a recursive technology in Graham's production. The camera obscura is an optical device (box or room with a small opening) whose original purpose was to allow the observer to see, to amplify and to represent natural phenomena. ${ }^{24}$ It played a major role in seventeenth- and eighteenthcentury Europe, in the very period when the modern conception of nation was starting to emerge, not only because it was used by many artists for the observation of nature, but also because it became, as Jonathan Crary has argued, an important metaphor for understanding the human mind. ${ }^{25}$ What type of space is the viewer occupying when situated inside the Canadian pavilion, tion and the beginning of a new paradigm of unity-withhybridity, they often fail to stress the role played by new images in the thinking of this major shift. Cinema, video, synthesized and computer-generated images broadcasted on public billboards, theatre screens, by television or on the Internet not only surround "us" as a spectacle to be looked at; they shape each citizen's identity, for the citizen is part of the spectacle s/he contemplates and which is continually, sensually and cognitively, affected by visual culture. Ardele Lister's Conditional Love is crucial in this regard because it succeeds in emphasizing the role of mass-media images in the performance of national identity. It is therefore imperative, and this is where lies the productivity of Vexation Island, to conceive the modalities of image processing so as to situate the agency of the producer and of the viewer in the formation of alternative representations of the nation. 
To conclude then, what does and how does belonging signify in the three "negotiation works" we have just examined? These media works break with the paradigm of homogenization and expand upon Benedict Anderson's insight that the experience of nationhood has been made possible by the development of mass media, notably the newspaper that introduced "mass ceremony" in the practice of readership. This new form of ceremony has played a major role in the constitution of the modern imagined nation. As Anderson writes:

\footnotetext{
The significance of this mass ceremony $[\ldots]$ is paradoxical. It is performed in silent privacy, in the lair of the skull. Yet each communicant is well aware that the ceremony he performs is being replicated simultaneously by thousands (or millions) of others of whose existence he is confident, yet of whose identity he has not the slightest notion. Furthermore, this ceremony is incessantly repeated at daily or half-daily intervals throughout the calendar. [...] At the same time, the newspaper reader, observing exact replicas of his own paper being consumed by his subway, barbershop, or residential neighbours, is continually reassured that the imagined world is visibly rooted in everyday life. As with Noli Me Tangere, fiction seeps quietly and continuously into realiry, creating that remarkable confidence of community in anonymity which is the hallmark of modern nation. ${ }^{27}$
}

As each citizen reads the newspaper, watches television, listens to the radio or browses through the Internet "in silent privacy," $s /$ he inscribes himself or herself in a mass ceremony. The interaction with mass media is the modality by which the subject becomes aware of his or her belonging to a collectivity even though $s$ /he does not know the members of that collectivity. This experience is the experience of nation as an abstraction, which pulls the subject out of his or her own private space. Our three negotiation works expand upon Anderson's insight, showing that video and cinema have become the new means of observation, representation, dissemination, dreaming and shaping of national belongings. But let us be clear about this: they expand but also break with this insight. Indeed, to belong here is not so much to unite, as in Anderson's conceptualization of nation; it is rather to live in the gap between two official languages, between video and cinema, between (American) presence and (Canadian) absence in cinema, between the projection and the fixation of dream images of the elsewhere. A gap is at play which puts "Canadian unity" into crisis. This gap has to be understood as a hybrid space which forms itself as a (schizophrenic, melancholic, natural or dreamlike) surge whose "sudden acceleration of sign-flow away from established meanings" (Griggers) activates incompatibilities between linguistic, cultural, geographic, technological categories.
This understanding of belonging, however, does not put an end to the modern construct of nation. What it does is to break with the unproductive dichotomy of the civic and the ethnic nation to think them together, showing how unity is constantly worked by gaps, and how hybridity is as much about mixture as it is about delay, lack, cleavage-in-process, intermediacy, inbetweenness. These surging aesthetic strategies complexify our perception of nation and problematize nation as the "only" valid means of social unity. The works not only question this value; they also attempt to think Canada differently, as a failed unity embodied by a being that does not fit the norm of bilingualism (Yes Sir! Madame ...), as a lack that is enunciated by a constant negotiation between cinema and video (Conditional Love), or as a dream image which can be re-processed by the citizen/viewer as $s /$ he is being affected by it (Vexation Island). Quebec and Canada are not powerful nations. Their identities have been marked from the start by cultural difference, and they may be breaking up soon. They certainly have a more fragile cultural foundation and a weaker sense of history-as-destiny compared to European nations, but as the historian Gérard Bouchard convincingly argues, it is precisely their constant need for negotiation that makes these nations so valuable for the rethinking of nation. It is also what the three media works are attempting to represent by drawing the viewer's attention to the complex networks of negotiations, mediations and intermediate organizations between the particular and the universal.

\section{Notes}

I wish to thank Vtape, Coop Video and Loretta Yarlow (Director, York Gallery) for allowing me to study parts of their collections. I could not have written this article without their flexibility and generosity of time.

1 Dominique Schnapper, La communauté des citoyens: sur l'idée moderne de nation (Paris, 1994), 14.

2 Schnapper, La communauté des citoyens, 92.

3 Schnapper, La communauté des citoyens, 15.

4 Schnapper, La communauté des citoyens, 11. Trans. C.R.

5 Gérard Bouchard, "Qu'est-ce qu'une nation ?", unpublished paper delivered at the "Nationalité, citoyenneté et solidarité" symposium organized by Le Groupe de recherche sur le nationalisme and the Department of Philosophy of the Université de Montréal, Montreal, 21-23 May 1998.

6 Cf. Homi Bhabha, ed., The Location of Culture (New York, 1994), and Bhabha, ed., Nation and Narration (New York, 1990); Yael Tamir, Liberal Nationalism (Princeton, 1993), and Tamir, "The Age of Atonement: The Changing of a Political Paradigm," unpublished paper delivered at the "Nationalité, citoyenneté et solidarité" symposium organized by Le Groupe de recherche sur le nationalisme and the Department of Philosophy of the Université de Montréal, 
Montreal, 21-23 May 1998; Gérard Bouchard, Entre l'Ancien et le Nouveau Monde: le Québec comme population neuve et culture fondatrice (Ottawa, 1996), Bouchard and Yvan Lamonde, eds, La nation dans tous ses états: le Québec en comparaison (Montreal, 1997), and Bouchard "Qu'est-ce qu'une nation?"

7 Tamir, "The Age of Atonement."

8 Bruno Latour, We Have Never Been Modern, trans. Catherine Porter (Hemel Hempstead, 1993).

9 Latour, We Have Never Been Modern, 112-13.

10 Bhabha, "Dissemination: Time, narrative and the margins of the modern nation", in Bhabha, ed., The Location of Culture, 147.

11 Bouchard, "Qu'est-ce qu'une nation ?"

12 Camilla Griggers, Becoming-woman, Theory out of Bounds, VIII (Minneapolis, 1997), 119.0.

13 Pierre Elliott Trudeau, Debates of the Senate, 2nd session, 3rd Parliament, vol. 132, 30 March 1998, 2993, quoted in Kenneth McRoberts, Misconceiving Canada: The Struggle for National Unity (Toronto, 1997), 107.

14 McRoberts, Misconceiving Canada, chap. 4 and 5.

15 Benedict Anderson, Imagined Communities: Reflections on the Origin and Spread of Nationalism (London, 1983), 15: "It is imagined because the members of even the smallest nation will never know most of their fellow-members, meet them, or even hear of them, yet in the minds of each lives the image of their communion."

16 On the limits of multiculturalism and its fragmenting effects, see
Neil Bissoondath, Selling Illusions: The cult of multiculturalism in Canada (Toronto, 1994).

17 Bouchard, "Qu'est-ce qu'une nation ?"

18 Jan Nederveen Pieterse, "Globalization as Hybridization, " in Mike Featherstone, Scott Lash and Roland Robertson, eds, Global Modernities (London, 1995), 62.

19 Bhabha, "Introduction: Locations of culture," in Bhabha, ed., The Location of Culture, 7.

20 Tamir, "The Age of Atonement."

21 Raymond Bellour, "Autoportraits," in Bellour and Anne-Marie Duguet, eds, Vidéo, Communications XLVIII, (1988), 342. Trans. C.R.

22 Susan Buck-Morss, The Dialectics of Seeing: Walter Benjamin and the Arcades Project (Cambridge, Mass., 1989), 81.

23 Robert Linsley, "A Voyage To and From Rodney Graham's Island of Vexation," in Island Thought: Canada XIVII Biennale di Venezia [an archipelagic journal published at irregular intervals], I (Summer 1997), 26-27.

24 Lesley Johnstone, "Sites of the Visual, " in Sites of the Visual, exh. cat., Art Gallery of Windsor (Windsor, 1997), 12.

25 Jonathan Crary, Techniques of the Observer: On Vision and Modernity in the Nineteenth Century (Cambridge, Mass., 1990).

26 Gilles Deleuze and Félix Guattari, A Thousand Plateaux: Capitalism and Schizophrenia (Minneapolis, 1987).

27 Anderson, Imagined Communities, 39-40. 